\title{
Population size assessment of the Endangered red-billed curassow Crax blumenbachii: accounting for variation in detectability and sex-biased estimates
}

\author{
Fernanda Alves, Germán M. López-Iborra and Luís Fábio Silveira
}

\begin{abstract}
The Endangered red-billed curassow Crax blumenbachii is endemic to the lowland Atlantic Forest of Brazil and is extinct across most of its range as a result of habitat loss and hunting pressure. Global population estimates are unreliable as the species has never been surveyed systematically. During March 2012-February 2013 we used line transects to estimate the density and size of one of the most important populations, in the Vale Nature Reserve. Using Distance we estimated a density of 1.3 individuals per $\mathrm{km}^{2}$; results stratified by sex indicated a male-skewed sex ratio. Data collected from motion-activated cameras confirmed that the population was male skewed but to a lesser degree than suggested by transect data. Sex-specific behavioural responses to the presence of an observer probably contributed to the difference between camera and transect data. Using the camera-derived sex ratios we corrected transect estimates to 1.6 individuals per $\mathrm{km}^{2}$ and a population of 325 individuals. Our systematic survey approach has revealed that Vale Nature Reserve has a larger population than previous estimates of the global population. We show that behavioural differences between the sexes in cryptic species can mislead population estimates, and we highlight the importance of motion-activated cameras as a tool for studying cryptic forest species.
\end{abstract}

Keywords Atlantic Forest, Brazil, camera trapping, Crax blumenbachii, detectability, distance sampling, management, population abundance, red-billed curassow

\section{Introduction}

eveloping conservation strategies for threatened species remains problematic because conservationists often lack empirical data concerning the population dynamics of the target species (Jones, 2004). Reliable estimates of

Fernanda Alves (Corresponding author) and Luís FÁbio Silveira Seção de Aves, Museu de Zoologia da Universidade de São Paulo, São Paulo, Brazil

E-mail fernandabiologia@gmail.com

Germán M. López-Iborra Departamento de Ecología/IMEM Ramon Margalef, Universidad de Alicante, Alicante, Spain

Received 9 December 2014. Revision requested 23 February 2015.

Accepted 20 May 2015. First published online 22 October 2015. population size are important for conservation planning and management (Bibby, 2000; Jones, 2004; Buckland et al., 2008) as they help to improve the efficacy of management and the likelihood of successful population recovery (Jones, 2004). Given that most recovery strategies are based on estimates of population size it is important that the techniques employed to derive estimates of population size are unbiased and reliable. However, obtaining abundance estimates with low bias and high precision is difficult, and therefore many bird studies present abundance indices rather than estimates (Buckland et al., 2008). Heterogeneity in population parameters that affect detection probability and influence the accuracy of results must be taken into account to avoid unreliable modelling and population estimates (Buckland et al., 2008; Ordóñez et al., 2011).

Cracids (curassows, guans and chachalacas) are endemic to the Neotropics and are one of the most threatened families of birds in the region (Sick, 1997; Delacour \& Amadon, 2004; Brooks \& Fuller, 2006). They play an important role in forest dynamics through seed dispersal and influencing plant population density (Santamaría \& Franco, 2000; Delacour \& Amadon, 2004; Brooks \& Fuller, 2006). Most cracids are threatened by habitat loss and hunting (Brooks \& Strahl, 2000; IUCN, 2014) but efforts to mitigate the impacts of anthropogenic threats are hindered by poor knowledge of their population ecology; for example, it is difficult to obtain population estimates of curassows because most species are cryptic and rare. Furthermore many cracids inhabit tropical forests, where visibility is low and access for observers can be difficult (Delacour \& Amadon, 2004).

Given the importance of population data for conservation management, testing the utility of existing approaches for estimating population sizes for cryptic species is a fundamental starting point. Distance sampling line transects are often used to estimate the abundance of cracids (Conroy \& Carroll, 2000; Haugaasen \& Peres, 2008; Barrio, 2011; Desbiez \& Bernardo, 2011; Setina et al., 2012). This approach relies on visual detections to estimate abundance, but for rare curassow species aural detections are also recorded to boost sample sizes (Cox et al., 1997; Jiménez et al., 2003) as the number of visual detections is usually low. During the breeding season male curassows produce a booming call that can be heard over long distances, which facilitates the location of male individuals by observers. Males are easier 


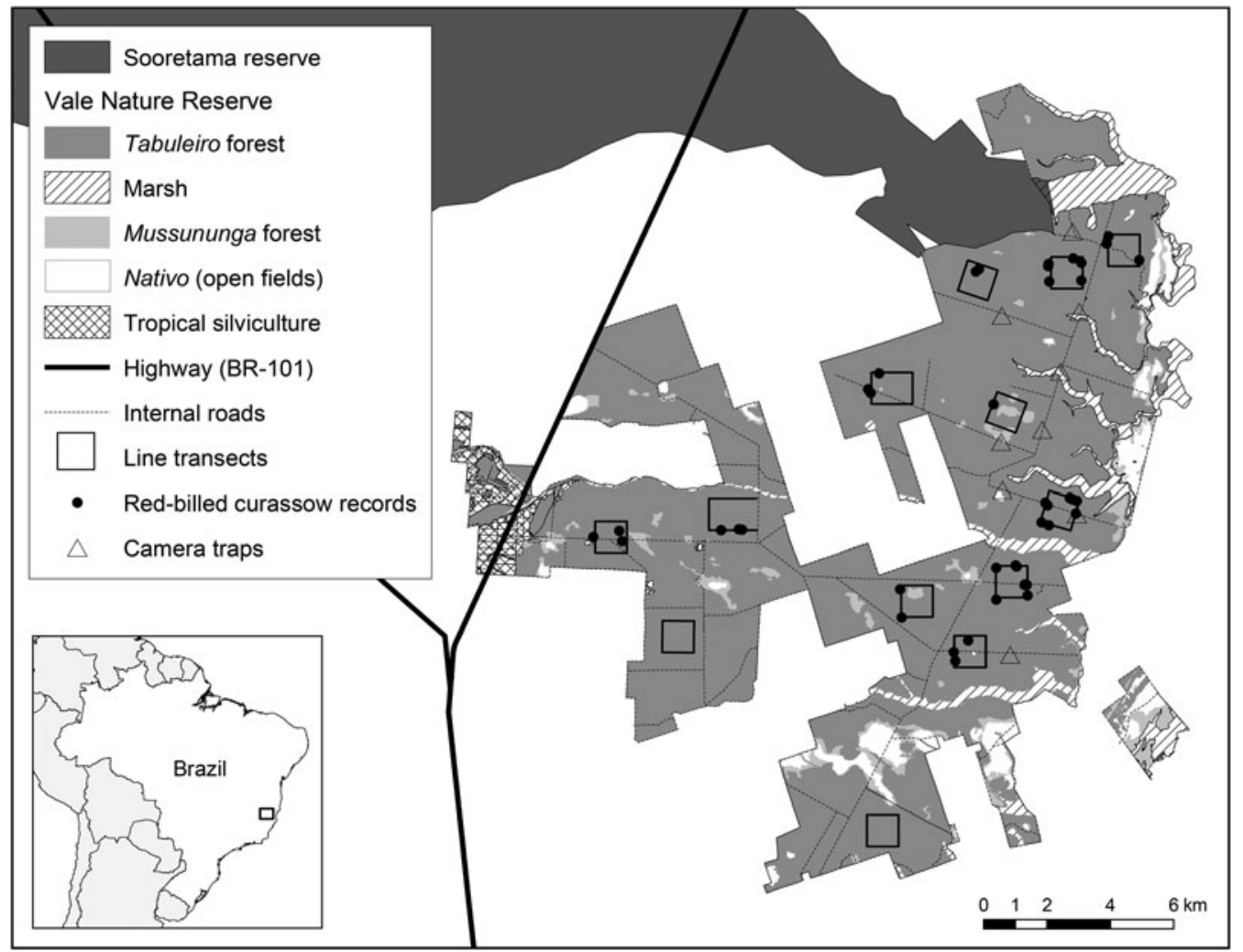

FIG. 1 The location of transects, camera traps, and records of red-billed curassows Crax blumenbachii in the study area in Vale Nature Reserve, Brazil.

to detect than females because of their alarm call and conspicuous behaviour, which facilitate detections at greater distances (e.g. Hill et al., 2008). Aural detections of curassows are therefore biased towards males (Jiménez et al., 2003) but this has been overlooked by previous studies.

The red-billed curassow Crax blumenbachii is endemic to lowland Atlantic Forest in Brazil. As a result of habitat loss and hunting pressure the species is extinct across most of its former range (Sick, 1997; Delacour \& Amadon, 2004; Silveira et al., 2004), and it is categorized as Endangered (MMA, 2003; BirdLife International, 2013; IUCN, 2014). Relict populations persist in isolated forest fragments in southern Bahia and northern Espírito Santo states but these wild populations have never been surveyed systematically (Sick, 1970; Collar \& Gonzaga, 1988). The aim of this work was to derive population density and size estimates for one of the most important remnant populations, taking into account behavioural differences between males and females that affect the probability of detection and bias population estimates. We also tested the veracity of sex biases detected using transect surveys by comparing with sex ratios estimated using motion-activated cameras. We present baseline data on the size of a red-billed curassow population in Espírito Santo and discuss the significance of our results for the conservation of this species in its remaining habitat.

\section{Study area}

We conducted field work at Vale Nature Reserve, a private reserve in northern Espírito Santo state, Brazil (Fig. 1). The Reserve comprises c. 23,00o ha of Atlantic Forest, one of the last patches of contiguous lowland Atlantic Forest in Brazil (BirdLife International, 2014a). Together with the nearby Sooretama Biological Reserve, Vale comprises c. $10 \%$ of the remaining Atlantic Forest in Espírito Santo and is an important site for the conservation of lowland Atlantic Forest biodiversity (UNESCO, 2013; Fundação SOS Mata Atlântica \& INPE, 2014). This forest remnant is also within an Important Bird Area (Bencke et al., 2006; BirdLife International, 2014a) and an Endemic Bird Area (Stattersfield et al., 1998; BirdLife International, 2014b).

Vale Nature Reserve is dominated by lowland Atlantic Coastal Forest and lies at an altitude of $28-65 \mathrm{~m}$. Tabuleiro forest (i.e. seasonal perennial forest) covers $68 \%$ of the Reserve, with the remainder covered by mussununga (i.e. forest growing on sandy soil) and nativo (open fields). The characteristic plant families in the region are Myrtaceae, Sapotaceae, Caesalpinioideae, Euphorbiaceae and Faboideae. The Reserve is embedded in a matrix dominated by agriculture and Eucalyptus spp. plantations (Jesus \& Rolim, 2005). The temperature range across one calendar year is $14.8-34.2^{\circ} \mathrm{C}\left(\right.$ mean $\left.23.3^{\circ} \mathrm{C}\right)$ and mean annual 
precipitation is $1,202 \mathrm{~mm}$, with a rainy season during October-March and a dry season during April-September (Jesus \& Rolim, 2005). According to Reserve staff, hunting pressure is lower than in other known areas with remnant curassow populations, probably because of the patrolling system in place.

\section{Methods}

\section{Population surveys}

We used a distance sampling line transect method (Buckland et al., 2001) to estimate the population density of the red-billed curassow. A total of 13 transects designed as square circuits of c. $4 \mathrm{~km}$ each were established in tabuleiro forest, which is considered typical habitat for the species. Transect starting points were selected at random over the study area, excluding unsuitable habitats (e.g. nativo). Three transects traversed mussununga forest, which is a transitional habitat within the tabuleiro forest (Fig. 1). We used square circuits for logistical reasons, to shorten the travel time between transects so we were able to cover two transects per day, walking at $1 \mathrm{~km} \mathrm{~h}^{-1}$ (Buckland et al., 2001, 2010). We conducted surveys early in the morning and in the afternoon, known activity peaks for red-billed curassows (Srbek-Araujo et al., 2012). On detecting a curassow we recorded the time, number of individuals, sex and location (using a global positioning system). We used a tape to measure the perpendicular distance from the transect to the point where each curassow was first detected.

We recorded both visual and aural detections (alarm calls, booming males), but only aural detections that were confirmed visually were included in our analysis. Males remain stationary while booming, so it is possible to locate them (Jiménez et al., 2003). Whenever we heard a booming male we walked slowly towards the call, and when we located the individual we measured its perpendicular distance from the transect (Jiménez et al., 2003).

Field work was carried out monthly during March 2012February 2013. Transects were surveyed at least once per month; because of logistical constraints only some transects were surveyed a second time each month. To address this we divided transects into two groups and each group received a second survey on alternate months, resulting in equal survey effort for all transects. One transect was not surveyed on one occasion because of flooding during November 2012. Transects were not surveyed during inclement weather. We walked a total of $868.6 \mathrm{~km}$ (303.3 in the non-breeding season and 565.3 in the breeding season). Field records and information from captive programmes suggest that the breeding season is September-February, with booming occurring mainly during September and November (Sick, 1970, 1997; Delacour \& Amadon, 2004, Silveira et al.,
2004). However, at Vale Nature Reserve the breeding season was assumed to occur during July-February, based on male booming behaviour (Sick, 1970; Delacour \& Amadon, 2004).

To evaluate possible bias in the sex ratio derived from transect surveys we used records of curassows obtained using motion-activated cameras (Bushnell Trophy Cam, Bushnell Outdoor Products, Overland Park, USA) distributed along unpaved roads at intervals of $2.35 \mathrm{~km}$. The cameras were part of a project to monitor jaguars Panthera onca in the Reserve, which began in 2005 (Srbek-Araujo \& Chiarello, 2013; Fig. 1). We used camera data collected during the sampling period that had the greatest overlap with our study period (June 2012-May 2013). Cameras were distributed throughout three sectors of the Reserve (north, south and west), with 10 stations in each sector. The sectors were sampled in sequence: 10 cameras were placed in the north area, then moved to the south and then to the west. The cameras were deployed in each sector for 2 months in the dry season and 2 months in the wet season. They were set to record $10 \mathrm{~s}$ videos when triggered, and operated 24 hours per day. A camera was included in the analysis only if it had accumulated $>20$ independent records of curassows, to ensure a representative sample of individuals of both sexes, and if the sex ratios detected by each camera had stabilized. Nine cameras satisfied these criteria (Fig. 1).

\section{Data analysis}

The area of potential curassow habitat (i.e. tabuleiro forest) in our analyses was 19,822 ha (c. $198.2 \mathrm{~km}^{2}$ ), calculated by excluding open fields and marshes in the Reserve. We used Distance v. 6.2 (Thomas et al., 2010) to estimate the density of red-billed curassows. We undertook exploratory analysis, examining histogram shapes using several cut points and quantile-quantile ( $\mathrm{q}-\mathrm{q}$ ) plots to check data behaviour and assumptions (Buckland et al., 2001). No problematic histogram shapes were identified and all tests associated with $\mathrm{q}-\mathrm{q}$ plots were non-significant. We used the raw distances recorded in the field in our analysis, and set truncation at $5 \%$ to avoid the need for extra adjustment terms to fit a model (Thomas et al., 2010). We performed an analysis stratifying data by breeding and non-breeding seasons to assess differences in detectability between seasons. Then, given the low number of records in the non-breeding season (Table 1) and the apparent differences in detection probability between seasons (see Results), we chose to analyse only data from the breeding season. As some of the contacts were of groups, sometimes including both sexes, we treated contacts as clusters.

During the surveys we observed behavioural differences between the sexes, with important implications for detectability. Whereas males emit a distinctive alarm call while 
TABLE 1 Numbers of red-billed curassows Crax blumenbachii recorded in Vale Nature Reserve, Brazil (Fig. 1), during the breeding and non-breeding seasons.

\begin{tabular}{|c|c|c|c|c|c|c|}
\hline \multirow[b]{2}{*}{ Season } & \multirow[b]{2}{*}{ Record $^{1}$} & \multicolumn{2}{|l|}{ Males } & \multicolumn{2}{|c|}{ Females } & \multirow{2}{*}{$\begin{array}{l}\text { Mixed } \\
\text { Clusters }\end{array}$} \\
\hline & & Single & Clusters & Single & Clusters & \\
\hline \multirow[t]{2}{*}{ Non-breeding } & Visual & 4 & 0 & 1 & 0 & 1 (1 male; 2 females) \\
\hline & Aural & 2 & 0 & 0 & 0 & 0 \\
\hline \multirow[t]{3}{*}{ Breeding } & Visual & 19 & 0 & 1 & 1 (2 females) & 4 (8 males; 4 females) \\
\hline & Aural & 10 & 0 & 0 & 0 & 0 \\
\hline & Booming/visual $^{2}$ & 8 & 0 & 0 & 0 & 3 ( 3 males; 3 females) \\
\hline
\end{tabular}

${ }^{1}$ Only visual and booming/visual records were included in the analyses.

${ }^{2}$ Booming males were first detected aurally and then visually.

TABLE 2 Models used to analyse all data, post-stratified by season, and data from the breeding season only, with the probability (P) of detecting a red-billed curassow in a defined area, coefficient of variation, and AICc.

\begin{tabular}{|c|c|c|c|}
\hline Model & $\mathrm{P}(95 \% \mathrm{CI})$ & Coefficient of variation & AICc \\
\hline \multicolumn{4}{|c|}{ All data, post-stratified by season } \\
\hline \multirow[t]{2}{*}{ Uniform cosine } & Breeding season: $0.60(0.50-0.73)$ & 9.76 & \multirow[t]{2}{*}{$337.62^{\star}$} \\
\hline & Non-breeding season: $0.50(0.18-1)$ & 40.72 & \\
\hline \multicolumn{4}{|c|}{ Breeding season data } \\
\hline Uniform cosine & $0.60(050-0.73)$ & 9.76 & 288.77 \\
\hline Hazard rate & $0.58(0.38-0.87)$ & 20.47 & 289.58 \\
\hline Half normal & $0.60(0.47-0.76)$ & 12.10 & 289.90 \\
\hline
\end{tabular}

${ }^{*}$ Best model in analysis of all data

walking away from a disturbance or after flying to a high perch, females usually skulk away or produce a low, barely audible dovelike sound (Sick, 1970; authors, pers. obs.). We therefore investigated sex-specific differences in detection probability. To do this we needed to replace clusters with individual contacts, but this violates the assumption of independence between contacts. To overcome this we followed the suggestion of Buckland et al. (2001) to select a model that uses clusters as the sampling unit, and then to refit the model to the data using individuals instead. For the models fitted to breeding season data we used various key functions (half-normal, uniform and hazard rate) with cosine series expansion to select the best models $(\triangle \mathrm{AICc}<2$; Burnham \& Anderson, 2002). These were then fitted to the transect data after clusters had been split into individual records to facilitate a separate estimate for each sex (Buckland et al., 2001; Thomas et al., 2010).

To include the effect of sex in the models we used two approaches. Firstly, we used the conventional distance sampling engine and post stratified data by sex to derive detectability estimates for males and females. We also analysed data using the multicovariate distance sampling engine, using sex as a covariate. Multicovariate distance sampling facilitates the inclusion of covariates other than distance that may affect detection, and performs better for small data sets (Marques \& Buckland, 2003, 2004). However, it assumes that the shape of the detection curve is the same for all covariate levels (i.e. male/female), whereas with poststratification using conventional distance sampling we were able to fit a specific detection function for each sex. Using the conventional distance sampling engine we first fitted the same detection function to both sexes (global models in Table 3) to derive density and population estimates for each sex, which may vary only as a result of their different encounter rates. Then we fitted a separated detection function for each sex to estimate sex-specific detection probabilities (female or male models in Table 3). In these models density and population estimates vary as a result of varying encounter rates and detection probabilities. We used $\mathrm{q}-\mathrm{q}$ plots and Kolmogorov-Smirnov tests to assess goodness of fit, which was generally good ( $\mathrm{P}>0.52$ in all cases; Thomas et al., 2010).

Using population estimates provided by Distance models for each sex, we calculated sex ratios as the estimated number of males divided by the estimated number of females. To estimate the sex ratio recorded by each camera trap we calculated the total number of independent males and females recorded by each camera. Unless videos showed obviously different individuals or groups, recordings of individuals or clusters were considered independent only if separated by at least 1 hour (O'Brien et al., 2003). Estimates were averaged over the nine selected traps, and their confidence intervals were estimated by non-parametric bootstrap using $R$ (R Development Core Team, 2014) and 10,00o re-samplings. In 
TABLE 3 Conventional and multicovariate distance sampling models used to analyse data for individual red-billed curassows in Vale Nature Reserve (Fig. 1), with detection function, AICc, Akaike weight, probability of detection (P), effective strip width (ESW, m), density (individuals per $\mathrm{km}^{2}$ ), coefficient of variation $(\mathrm{CV})$, and population size $(\mathrm{N})$ in the study area.

\begin{tabular}{|c|c|c|c|c|c|c|c|c|c|}
\hline & Function & AICc & $\begin{array}{l}\text { Akaike } \\
\text { weight }\end{array}$ & $\mathrm{P}(95 \% \mathrm{CI})$ & ESW $(95 \% \mathrm{CI})$ & \multicolumn{2}{|c|}{ Density $(95 \% \mathrm{CI})$} & $\mathrm{CV}$ & $\mathrm{N}(95 \% \mathrm{CI})$ \\
\hline \multicolumn{10}{|c|}{ Conventional distance sampling models ${ }^{*}$} \\
\hline \multirow{4}{*}{$\begin{array}{l}\text { Uniform } \\
\text { cosine }\end{array}$} & Global & 352.49 & 0.240 & $0.56(0.49-0.64)$ & $30.8(26.8-35.4)$ & Female & $0.29(0.13-0.62)$ & 36.75 & $57(26-123)$ \\
\hline & & & & & & Male & $1.04(0.56-1.91)$ & 28.94 & $205(111-378)$ \\
\hline & Female & 354.16 & 0.104 & $0.50(0.30-0.82)$ & $27.5(16.7-45.2)$ & Female & $0.32(0.14-0.75)$ & 42.36 & $64(27-149)$ \\
\hline & Male & & & $0.57(0.48-0.68)$ & $31.5(26.5-37.5)$ & Male & $1.01(0.55-1.87)$ & 29.35 & $200(108-371)$ \\
\hline \multirow[t]{4}{*}{ Half normal } & Global & 353.15 & 0.172 & $0.54(0.43-0.67)$ & $29.5(23.7-36.7)$ & Female & $0.29(0.14-0.65)$ & 37.68 & $59(27-130)$ \\
\hline & & & & & & Male & $1.08(0.58-2.02)$ & 30.12 & $214(114-400)$ \\
\hline & Female & 355.24 & 0.061 & $0.46(0.25-0.85)$ & $25.3(13.8-46.6)$ & Female & $0.35(0.14-0.86)$ & 45.33 & $69(28-170)$ \\
\hline & Male & & & $0.56(0.44-0.71)$ & $30.7(24-39.3)$ & Male & $1.04(0.55-1.95)$ & 30.62 & $206(109-387)$ \\
\hline \multirow[t]{4}{*}{ Hazard rate } & Global & 352.40 & 0.251 & $0.57(0.42-0.76)$ & $31.1(23.1-41.8)$ & Female & $0.28(0.13-0.63)$ & 39.00 & $56(25-125)$ \\
\hline & & & & & & Male & $1.03(0.54-1.96)$ & 31.76 & $203(106-388)$ \\
\hline & Female & 357.61 & 0.019 & $0.54(0.30-0.96)$ & $29.4(16.4-52.7)$ & Female & $0.30(0.12-0.73)$ & 44.27 & $60(24-144)$ \\
\hline & Male & & & $0.58(0.41-0.82)$ & $32(22.7-45)$ & Male & $0.99(0.51-1.94)$ & 32.81 & $198(102-384)$ \\
\hline \multicolumn{10}{|c|}{ Multicovariate distance sampling models } \\
\hline \multirow[t]{2}{*}{ Half normal } & Female & 354.90 & 0.072 & $0.46(0.27-0.80)$ & $25.3(14.7-43.8)$ & Female & $0.35(0.15-0.83)$ & 43.77 & $69(29-165)$ \\
\hline & Male & & & $0.56(0.44-0.70)$ & $30.7(24.4-38.6)$ & Male & $1.04(0.55-1.94)$ & 30.25 & $206(110-385)$ \\
\hline \multirow[t]{2}{*}{ Hazard rate } & Female & 354.65 & 0.081 & $0.55(0.33-0.92)$ & $30.4(18.2-50.8)$ & Female & $0.29(0.12-0.68)$ & 42.83 & $58(24-136)$ \\
\hline & Male & & & $0.55(0.44-0.70)$ & $30.5(24.2-38.4)$ & Male & $1.04(0.56-1.96)$ & 30.31 & $207(110-388)$ \\
\hline
\end{tabular}

* For conventional distance sampling models each detection function was fitted in two ways: a common function for both sexes (Global) and a separate function for each sex, thus providing a sex-specific detection probability.

the same way we also calculated the mean proportion (and confidence intervals) of contacts involving females not accompanied by males.

\section{Results}

\section{Curassow population density}

We recorded 42 visual detections of red-billed curassows (56 individuals in total, including booming males that were detected both aurally and visually) and 12 aural detections (Table 1). Most visual encounters were of individuals $(\mathrm{n}=33)$, with the remainder recorded in nine clusters (23 individuals in total). Curassows were usually detected on the ground but also in the sub-canopy and canopy, especially when booming.

Analysis of data stratified by breeding and non-breeding season showed a lower detection probability and low precision for the non-breeding season estimate as a result of the low number of contacts recorded (Table 2). Thus only data from the breeding season were used in subsequent analyses. Analysis of the breeding season data as clusters revealed similar AICc values across all fitted models $(\Delta \mathrm{AICc}<2$; Table 2), so we used all fitted models for the final analyses, where individual detections were analysed (Table 3). In these analyses conventional distance sampling models that estimated a common detection function for males and females had lower AICc values than models with a separate function for each sex (i.e. AICc $\leq 2$ within a given detection function except for hazard-rate models; Table 3). Suitability of multicovariate distance sampling models was similar to that of conventional distance sampling models, with separate functions for sex according to AICc. The sum of Akaike weights for models with equal detectability for the sexes was 0.633 , and 0.337 for the sex-specific detectability models. Thus the differences between sexes in detection probability could not be ignored.

Conventional distance sampling models using sex-specific detection functions estimated lower detection probabilities and higher population estimates for females than models with a common detection probability for both sexes. Given that most records were of males $(79.2 \%)$ and only two (6.2\%) were of females not accompanied by males, detectability estimates produced by models using the same detection function for both sexes were biased towards male values. Consequently, female density and population estimates are lower than those produced by models that estimate sexspecific detectability using the same function. The model with the lowest AICc value using a common detection function (hazard rate) produced a pooled density estimate of 1.3 (range 0.6-2.6) individuals per $\mathrm{km}^{2}$ and a population estimate of 203 males and 56 females. The lowest AICc model with a separate detection function for each sex (uniform cosine) estimated 200 males and 64 females. These results corresponded to a sex ratio of 3.6 males per female $\left(95 \% \mathrm{CI}_{3.1} .4 .4\right.$, calculated from $95 \% \mathrm{CI}$ limits for population estimates) and 3.1 males per female (95\% CI 2.5-4), respectively. The other models produced similar results both for population estimates (198-214 males, 56-69 females) and sex ratios (range 3.1-3.5). 


\section{Density and population estimates corrected for sex ratio}

Cameras operated for a mean of 81 days (range $38-96$ ), and 360 independent records of curassows were accumulated at the nine trapping stations (mean 40 records per camera, range $28-81$ ). Detections usually involved males (49.2\%) but unaccompanied females (22.8\%) were also recorded, as were both sexes together (28.1\%). The mean percentage of contacts with females not accompanied by males was $23.9 \%$ in camera records ( $95 \%$ CI 19-29.3), compared with $6.2 \%$ on transects.

Using cameras we estimated a mean sex ratio of 1.6 males per female ( $95 \%$ CI 1.3-2.0, which did not include equal sex ratio or overlap with the confidence interval estimated from distance sampling results). It was possible to estimate the number of females in the population by dividing the number of males and the confidence interval estimated by the best Distance model with sex-specific detection function (uniform cosine) by the camera trap sex ratio and its confidence interval. Using this approach we estimated a female population of 125 individuals (range 83-185). Using this corrected value the pooled density for both sexes was estimated to be 1.6 individuals per $\mathrm{km}^{2}$ (range 1.0-2.8), which equated to a corrected population estimate of 325 individuals (range 191-556) in our study area.

\section{Discussion}

This is the first study to estimate the size of a wild red-billed curassow population using intensive, replicable and standardized methods. Distance sampling is a robust statistical method that has been used to estimate the abundance of cracids (e.g. Cox et al., 1997; Begazo \& Bodmer, 1998; Desbiez \& Bernardo, 2011). However, to the best of our knowledge, variation in detection probability as a result of sexually dimorphic behavioural traits are seldom reported (e.g. Hill et al., 2008) and have not been accounted for in data analysis, which may be related to the difficulty in detecting lone females. Our results reveal that it is difficult to estimate sex-specific detection probabilities for curassows using distance sampling. Akaike weights provide some evidence for sex-specific models but it is difficult to achieve unbiased estimates of female detectability because females tend to be recorded with males, whereas most males were recorded alone. Males have higher detectability because of their conspicuous behaviours (i.e. calling and taking flight when disturbed) whereas females are more secretive and therefore less detectable. Consequently, estimates of female detection probability are biased towards male values and this leads to underestimation of female density and population. The effort required to increase the number of records of lone females makes this an unrealistic approach.

Failure to account for sex-specific detection probabilities may bias population estimates for one sex, and therefore bias estimates of sex ratios. This appears to have occurred in our analysis. Sex ratios derived from distance sampling were 3.1-3.6 males per female, whereas cameras yielded a lower sex ratio of 1.6 males per female. We consider that detection probabilities derived from cameras are less biased because both sexes are equally likely to trigger a camera, whereas an observer is more likely to detect a male curassow because of their conspicuous auditory cues. Camera data could be affected by local biases in the sex composition of the individuals moving around cameras, but our cameras were distributed widely in the Reserve and we have no reason to suspect a difference in the distribution of males and females. Both male and female curassows are known to utilize roads, and therefore deployment of cameras on roads is unlikely to have biased detection probabilities. We therefore suggest that camera data reflect the sex composition of the population more accurately than transect-derived data. Our results indicate that the red-billed curassow population in Vale Nature Reserve has a male-skewed sex ratio but given the overestimation of female detectability this skew is less severe than our distance analysis implies.

Few studies report skewed sex ratios in cracids but those that do usually report a female skew attributed to hunting of booming males by poachers (Sedaghatkish \& Brooks, 1999; Martínez-Morales et al., 2009). Hunting has been one of the main threats to the red-billed curassow throughout its range (Sick, 1997; Delacour \& Amadon, 2004) and is still common, especially in southern Bahia. However, the birds do not seem to be targeted by poachers at the Reserve, where there is an effective patrolling system in place, and therefore reduced hunting pressure may explain the lack of a female-skewed sex ratio in our study. To our knowledge only Hill et al. (2008) previously reported a male-skewed sex ratio; they found that $71 \%$ of transect records of the wattled curassow Crax globulosa were of males (equivalent to a sex ratio of $2.4: 1$ ) but using data from territory mapping only $55 \%$ of records were of males (sex ratio $1.2: 1$ ). Donald (2007) showed that a skewed adult sex ratio is common in bird populations and that it is more frequently male-skewed, especially in threatened species. Nonetheless, it can be difficult to explain the adult sex ratio as it may be influenced by a variety of factors (Donald, 2007). More research is needed to understand the mechanisms underlying this skewed sex ratio. Nest predation may be one of the causes as females are more vulnerable to predation when protecting their nests. Another hypothesis is related to variation in breeding or natal dispersal; in birds, dispersal is usually biased towards females (Greenwood \& Harvey, 1982; Clarke et al., 1997). Thus, females may be dispersing to areas where they are more exposed to threats related to edge effects, such as generalist predators or poorer habitat quality.

The global population of red-billed curassows was previously estimated, with low reliability, to be $\leq 250$ individuals (BirdLife International, 2013) but we have shown that Vale 
Nature Reserve alone may support many more individuals. Using distance sampling we estimated a population size of 264 individuals at the Reserve, and accounting for sexspecific detection probabilities our corrected population estimate is 325 . The estimated density of red-billed curassows in our study (1.3 individuals per $\mathrm{km}^{2}$; corrected estimate 1.6 individuals per $\mathrm{km}^{2}$ ) is similar to that of other curassows, such as Crax rubra griscomi (1.02; Martínez-Morales et al., 2009), Pauxi tuberosa (1.11-1.65; Haugaasen \& Peres, 2008) and Crax alberti (1.66; González, 2004). However, higher densities have been recorded for other species; for example, Pauxi pauxi (4.8; Setina et al., 2012), C. globulosa (3.4; Hill et al., 2008) and Crax fasciolata (4.66; Desbiez \& Bernardo, 2011). As curassows are vulnerable to habitat loss and fragmentation (Thornton et al., 2012), differences in population density among species are usually related to the level of habitat disturbance, hunting pressure or the recovery of previously hunted populations (Begazo \& Bodmer, 1998; Brooks, 1999).

Although our results are good news for conservation of the species, more work is needed to assess the status of other populations of red-billed curassows. Extrapolating our estimates to derive a global population estimate for the species is not appropriate because there is likely to be significant variation in population parameters between habitat patches as a result of variations in hunting pressure, predation and carrying capacity. We could cautiously extrapolate our estimates to the adjacent Sooretama Biological Reserve, as rangers from Vale Nature Reserve work together with public rangers and also patrol Sooretama, but despite the patrolling hunting is still more intense in Sooretama than in Vale. If our density estimate were applicable to the c. 25,00o ha of Sooretama (we cannot be sure of the area covered by tabuleiro forest as we did not have access) it could hold a population of similar size to that estimated at Vale. However, the two reserves are separated by a highway, which may be a barrier for this species as curassows are not able to sustain flight. If these forest fragments were connected and hunting control were improved there could be a functional population of almost 700 individuals, which would be good news for conservation of the red-billed curassow and other species that rely on protection of the remaining patches of Atlantic Forest.

The population of red-billed curassows must be estimated at other sites for a better evaluation of the global status of the species and the threats it faces under various levels of forest protection. Our findings suggest that surveying is most effective during the breeding season, when curassows are more easily detectable. We suggest that future surveys consider the effect of sex-specific variability in detection. Population estimates of other species of cracids with similar differences in behaviour between the sexes may be underestimated if they are based only on Distance analysis. Given the challenges involved in attaining the minimum recommended sample sizes (Buckland et al., 2001) for rare and cryptic species, alternative approaches such as the use of motion-activated cameras and abundance models that do not require identification of individuals make a better use of scarce resources when detections are infrequent (O'Brien \& Kinnaird, 2008; Fiske \& Chandler, 2011; Suwanrat et al., 2015). However, these methods require the estimation of additional parameters, such as home range and trap effective sampling area, which are currently unknown for the red-billed curassow.

Red-billed curassows are representative of the challenges involved in conservation of Neotropical birds. Our study provides valuable baseline information for an important population of red-billed curassows, and draws attention to the potential pitfalls of failing to account for sexually dimorphic behaviours.

\section{Acknowledgements}

This study was funded by Conservation des Espèces et des Population Animales, the Mohamed bin Zayed Species Conservation Fund, Idea Wild and Vale Nature Reserve. FA and LFS were supported by São Paulo Research Foundation (FAPESP) and Conselho Nacional de Desenvolvimento Científico e Tecnológico (CNPq). FAPESP also provided a 4-month Research Internship Abroad, which enabled FA to carry out data analyses at Alicante University in Spain. We thank Ana Carolina Srbek-Araujo for providing the camera trap data, and Dejan Stojanovic, Huw Lloyd and two anonymous reviewers for their helpful comments. We also thank our field assistants.

\section{References}

B ARrio, J. (2011) Hunting pressure on cracids (Cracidae: Aves) in forest concessions in Peru. Revista Peruana de Biología, 18, 225-230.

Begazo, A.J. \& Bodmer, R.E. (1998) Use and conservation of Cracidae (Aves: Galliformes) in the Peruvian Amazon. Oryx, 32, 301-309.

Bencke, G.A., Maurício, G.N., Develey, P.F. \& Goerck, J.M. (2006) Áreas Importantes para a Conservação das Aves no Brasil. Parte I: Estados do Domínio da Mata Atlântica. SAVE Brasil, São Paulo, Brazil.

Вівву, С. (2000) Why count birds? In Expedition Field Techniques: Bird Surveys (eds C. Bibby, M. Jones \& S. Marsden), pp. 5-11. BirdLife International, Cambridge, UK.

Birdife International (2013) Crax blumenbachii. In The IUCN Red List of Threatened Species v. 2014.2. Http://www.iucnredlist.org [accessed 6 August 2014].

Birdife International (2014a) Important Bird Areas factsheet: Sooretama/Linhares. Http://www.birdlife.org/datazone/ sitefactsheet.php?id=20140 [accessed 10 August 2014].

Birdife International (2014b) Endemic Bird Areas factsheet: Atlantic forest lowlands. Http://www.birdlife.org/datazone/ ebafactsheet.php?id=71 [accessed 10 August 2014]. 
Brooks, D.M. (1999) Pipile as a protein source to rural hunters and Amerindians. In Biology and Conservation of the Piping Guans (Pipile) (eds D.A. Brooks, A. Begazo \& F. Olmos), pp. 42-50. Special Publication Cracid Specialist Group, Houston, USA.

Brooks, D.M. \& Strahl, S.D. (200o) Curassows, Guans and Chachalacas. Status Survey and Conservation Action Plan for Cracids 2000-2004. IUCN/SSC Cracid Specialist Group, IUCN, Gland, Switzerland and Cambridge, UK.

Brooks, D.M. \& FULLER, R.A. (2006) Biology and conservation of cracids. In Conserving Cracids: The Most Threatened Family of Birds in the Americas (eds D.M. Brooks, L. Cancino \& S.L. Pereira), pp. 14-26. Houston Museum of Natural Science, Houston, USA.

Buckland, S.T., Anderson, D.R., Burnham, K.P., Laake, J.L., Borchers, D.L. \& Thomas, L. (2001) Introduction to Distance Sampling: Estimating Abundance of Biological Populations. Oxford University Press, Oxford, UK.

Buckland, S.T., Marsden, S.J. \& Green, R.E. (2008) Estimating bird abundance: making methods work. Bird Conservation International, 18, 91-108.

Buckland, S.T., Plumptre, A.J., Thomas, L. \& Rexstad, E.A. (2010) Design and analysis of line transect surveys for primates. International Journal of Primatology, 31, 833-847.

Burnham, K.P. \& Anderson, D.R. (2002) Model Selection and Multimodel Inference: A Practical Information-Theoretic Approach, 2nd edition. Springer-Verlag, New York, USA.

Clarke, A.L., SÆther, B.E. \& Røskaft, E. (1997) Sex biases in avian dispersal: a reappraisal. Oikos, 79, 429-438.

Collar, N.J. \& Gonzaga, L.A.P. (1988) O mutum Crax blumenbachii na Reserva Florestal Particular de Linhares-ES. Espaço, Ambiente e Planejamento, 2, 3-34.

Conroy, M. \& Carroll, J. (200o) Estimating abundance of Galliformes: tools and their application. In Galliformes 2000: Proceedings of the and International Galliformes Symposium. Woodburn, M.I.A. (eds P.J.K. McGowan, J.P. Carroll, A.H. Musavi $\&$ Z. Zheng-wang), pp. 204-215. King Mahendra Trust for Nature Conservation, Kathmandu, Nepal, and World Pheasant Association, Reading, UK.

Cox, G., Read, J.M., Clarke, R.O.S. \& Easty, V.S. (1997) Studies of horned curassow Pauxi unicornis in Bolivia. Bird Conservation International, 7, 199-211.

Delacour, J. \& Amadon, D. (2004) Curassows and Related Birds, 2nd edition. Lynx Edicions, Barcelona, Spain.

Desbiez, A.L. \& Bernardo, C.S. (2011) Density estimates of the bare-faced curassow (Crax fasciolata) in the Brazilian Pantanal. Revista Brasileira de Ornitologia, 19, 385-39o.

Donald, P.F. (2007) Adult sex ratios in wild bird populations. Ibis, 149, 671-692.

Fiske, I.J. \& ChandleR, R.B. (2011) unmarked: An R package for fitting hierarchical models of wildlife occurrence and abundance. Journal of Statistical Software, 43, 1-23.

Fundação SOS Mata Atlântica \& INPE (2014) Atlas dos Remanescentes Florestais da Mata Atlântica: Período 2012-2013. Fundação SOS Mata Atlântica and Instituto Nacional de Pesquisas Espaciais, São Paulo, Brazil.

González, J.D. (2004) Estimación de la densidad poblacional del Paujíl de Pico Azul Crax alberti (Aves: Cracidae) en el Nordeste Antioqueño, Colombia. Becas IEA, Bogota, Colombia.

Greenwood, P. \& Harvey, P.H. (1982) The natal and breeding dispersal of birds. Annual Review of Ecology and Systematics, $13,1-21$.

Haugaasen, T. \& Peres, C.A. (2008) Population abundance and biomass of large-bodied birds in Amazonian flooded and unflooded forests. Bird Conservation International, 18, 87-101.
Hill, D.L., Arañibar-Rojas, H. \& MacLeod, R. (2008) Wattled curassows in Bolivia: abundance, habitat use, and conservation status. Journal of Field Ornithology, 79, 345-351.

IUCN (2014) The IUCN Red List of Threatened Species v. 2014.3. Http://www.iucnredlist.org [accessed 6 August 2014].

Jesus, R.M. \& Rolim, S.G. (2005) Fitossociologia da Mata Atlântica de Tabuleiro. Boletim Técnico da Sociedade de Investigações Florestais, $19,1-149$.

Jiménez, I., Londoño, G.A. \& Cadena, C.D. (2003) Efficiency, bias, and consistency of visual and aural surveys of curassows (Cracidae) in tropical forests. Journal of Field Ornithology, 74, 210-216.

Jones, C.G. (2004) Conservation management of endangered birds. In Bird Ecology and Conservation: A Handbook of Techniques (eds W. J. Sutherland, I. Newton \& R.E. Green), pp. 269-293. Oxford University Press, New York, USA.

Marques, F.F.C. \& Buckland, S.T. (2003) Incorporating covariates into standard line transect analyses. Biometrics, 59, 924-935.

Marques, F.F.C. \& BuCKLAnd, S.T. (2004) Covariate models for the detection function. In Advanced Distance Sampling: Estimating Abundance of Biological Populations (eds S.T. Buckland, D. R. Anderson, K.P. Burnham, J.L. Laake, D.L. Borchers \& L. Thomas), pp. 31-47. Oxford University Press, Oxford, UK. Martínez-Morales, M.A., Cruz, P.C. \& Cuarón, A.D. (2009) Predicted population trends for Cozumel curassows (Crax rubra griscomi): empirical evidence and predictive models in the face of climate change. Journal of Field Ornithology, 80, 317-327.

MMA (Ministério do Meio Ambiente) (2003) Lista das Espécies da Fauna Brasileira Ameaçadas de Extinção. Instrução Normativa $\mathrm{n}^{\circ}$. 3, de 27 de maio de 2003. Diário Oficial da República Federativa do Brasil, Brasília, Brazil.

O'BRIEn, T.G. \& KinNAiRd, M.F. (2008) A picture is worth a thousand words: the application of camera trapping to the study of birds. Bird Conservation International, 18, 144-162.

O’Brien, T.G., Kinnaird, M.F. \& Wibisono, H.T. (2003) Crouching tigers, hidden prey: Sumatran tiger and prey populations in a tropical forest landscape. Animal Conservation, 6, 131-139.

Ordónez, A., van Loon, E. \& Bouten, W. (2011) Effects of population variability on the accuracy of detection probability estimates. Anales de Biología, 33, 149-160.

R Development Core Team (2014) R: A Language and Environment for Statistical Computing. R Foundation for Statistical Computing, Vienna, Austria.

Santamaría, M. \& Franco, A.M. (2000) Frugivory of Salvin's curassow in a rainforest of the Colombian Amazon. The Wilson Bulletin, 112, 473-481.

Sedaghatkish, G. \& Brooks, D.M. (1999) Retraso evolutivo en los crácidos: Cantado para ser la cena del cazador. In Manejo y conservación de fauna silvestre en América Latina (eds T.G. Fang, O. L. Montenegro \& R.E. Bodmer), pp. 335-340. Instituto de Ecología, La Paz, Bolivia.

Setina, V., Lizcano, D.J., Brooks, D.M. \& Silveira, L.F. (2012) Population density of the helmeted curassow (Pauxi pauxi) in Tamá National Park, Colombia. The Wilson Journal of Ornithology, 124, 316-320.

Sick, H. (1970) Notes on Brazilian Cracidae. The Condor, 72, 106-108. Sick, H. (1997) Ornitologia Brasileira. Editora Nova Fronteira, Rio de Janeiro, Brazil.

Silveira, L.F., Olmos, F. \& Bianchi, C. (2004) Plano de ação do mutum-do-sudeste Crax blumenbachii. Série Espécies Ameaçada. Ministério do Meio Ambiente, Brasília, Brasil.

Srbek-Araujo, A.C. \& Chiarello, A.G. (2013) Influence of camera-trap sampling design on mammal species capture rates and community structures in southeastern Brazil. Biota Neotropica, 13, $51-62$. 
Srbek-Araujo, A.C., Silveira, L.F. \& Chiarello, A.G. (2012) The red-billed curassow (Crax blumenbachii): social organization and daily activity patterns. The Wilson Journal of Ornithology, 124, 321327.

Stattersfield, A.J., Crosby, M.J., Long, A.J. \& Wege, D.C. (1998) Endemic Bird Areas of the World: Priorities for Biodiversity Conservation. BirdLife International, Cambridge, UK.

Sumanrat, S., Ngoprasert, D., Sutherland, C., Suwanwaree, P. \& SAVINI, T. (2015) Estimating density of secretive terrestrial birds (Siamese fireback) in pristine and degraded forest using camera traps and distance sampling. Global Ecology and Conservation, 3, 596-606.

Thomas, L., Buckland, S.T., Rexstad, E.A., Laake, J.L., Strind berG, S., Hedley, S.L. et al. (2010) Distance software: design and analysis of distance sampling surveys for estimating population size. Journal of Applied Ecology, 47, 5-14.

Thornton, D.H., Branch, L.C. \& Sunquist, M.E. (2012) Response of large galliforms and tinamous (Cracidae, Phasianidae,
Tinamidae) to habitat loss and fragmentation in northern Guatemala. Oryx, 46, 567-576.

UNESCO (2013) World Heritage list: Discovery Coast Atlantic Forest Reserves. Http://whc.unesco.org/en/list/892 [accessed 8 November 2013].

\section{Biographical sketches}

Fernanda Alves is a conservation biologist. Her research interests include population ecology, conservation and management of threatened bird species. Germán M. López-IBorRa works on the distribution, population dynamics and breeding biology of birds. He is especially interested in the conservation of scarce and threatened species. LUÍS FÁBIO SILVEIRA works on taxonomy and conservation of Neotropical birds. He is an associate researcher of the World Pheasant Association and has a special interest in the conservation of cracid species. 